\title{
Tingkat Partisipasi Masyarakat Lokal dalam Pengelolaan Ekowisata di Kampung Saporkren Distrik Waigeo Selatan Kabupaten Raja Ampat
}

\section{Participation Levels of Local Community for Ecotourism Management at Saporkren Village South Waigeo Raja Ampat District}

\author{
Ellen Tanati ${ }^{1}$, Wahyudi ${ }^{*}$, Anton Silas Sinery ${ }^{2}$ \\ ${ }^{1}$ Program Pasca Sarjana Ilmu Lingkungan, Universitas Papua Manokwari, 98314, Indonesia \\ ${ }^{2}$ Jurusan Kehutanan, Fakultas Kehutanan, Universitas Papua Manokwari, 98314, Indonesia \\ *Korespondensi: w.sayutipono@unipa.ac.id
}

\begin{abstract}
ABSTRAK
Kampung Saporkren Raja Ampat merupakan salah satu ikon ekowisata berbasis masyarakat lokal di Provinsi Papua Barat. Partisipasi masyarakat lokal dalam pengelolaan ekowisata sangat beragam, baik peran, unsur kelompok, maupun bentuk kegiatannya, sehingga diperlukan kajian tetang tingkat partisipasi. Penelitian ini bertujuan untuk mengetahui tingkat, fungsi/bentuk dan intensitas partisipasi lima kelompok responden masyarakat lokal (kepala/pemimpin, kelompok minat, anggota rumah tangga, wanita dan remaja), faktor-faktor yang mempengaruhi dan manfaat partisipasi pengelolaan ekowisata. Penelitan ini dilakukan dengan survey, dan wawancara semi struktural berpedoman kepada daftar pertanyaan. Hasil penelitian menunjukkan bahwa tingkat partisipasi empat kelompok responden dikategorikan sangat tidak aktif (1-25), dengan nilai indeks participation-empowerment index (PEI) di bawah 25, bahkan tingkat partisipasi kelompok responden remaja adalah nihil. Kepala/pemimpin memiliki fungsi partisipasi dalam perencanaan dengan intensitas pada pengendalian dan pengambilan keputusan. Kelompok anggota rumah tangga, kelompok minat dan wanita memiliki fungsi implementasi, perawatan, dan distribusi dengan intensitas pada pengambilan keputusan, konsultasi, dan memberi informasi. Akan tetapi kelima kelompok responden absen dalam fungsi partisipasi manajemen dengan intensitas partisipasi pada inisiasi kegiatan. Penyuluhan instansi teknis (70.8\%), ajakan instansi teknis (41.7\%), dan memperoleh pendapatan (37.5\%) merupakan tiga faktor dominan yang mendorong partisipasi masyarakat lokal. Destinasi ekowisata, pendapatan melalui homestay, motorist, dan pemandu wisata, terbentuknya kelompok tani hutan, kader konservasi alam, smart patrol adalah beberapa manfaat dari partisipasi tersebut. Pendampingan dalam hal manajemen, inisiasi kegiatan dan keterlibatan kelompok remaja adalah tiga hal penting perlu dipertimbangkan dalam peningkatan tingkat partisipasi masyarakat lokal dalam pengelolaan ekowisata di Kampung Saporkren.
\end{abstract}

Kata kunci: Partisipasi; masyarakat lokal; Saporkren; Ekowisata; Raja Ampat

\begin{abstract}
Saporkren village at Raja Ampat Islands is well-known for international and domestic icons for community based ecotourism in West Papua Province. This research is designed to investigate the levels of participation, functions and intensity of five groups of respondents (leader, interested group, family members, women, and teenager), influenced factors and benefits received from participation are also investigated. The results indicated that levels of participation of five groups of respondents are classified into extremely inactive (1-25) with an average for their index PEI of less than 25, and levels of participation for children are absent. Leaders had function in planning with intensity for total control and decision making. Other respondent of interested groups, family members and women had funstions in implementation, maintenance, and distribution with intensity for decision making, consultation, and information. However, five groups of respondents are absent in management function and initiation action of intensity involvement.
\end{abstract}


Counseling from official government (70.8\%), invitation from local officer (41.7\%), and income generating $(37.5 \%)$ are three main factors influenced the local community interested in ecotourism participation. Various direct and indirect benefits from ecotrourism management are confirmed such as famous ecotourism destination, local entrepreneur (homestay, handycraft, local cuisine), tour guides, local nature conservation guards, motorist, and the others. Three important issues for ecotourims based community in Saporkren village are management, initiation action, and absence of the teenagers in levels of participation.

Keywords: Participations; local community; Saporkren, ecotourism; Raja Ampat

\section{PENDAHULUAN}

Kepulauan Raja Ampat adalah salah satu ikon pariwisata khususnya ekowisata, di Provinsi Papua Barat. Gugusan pulau karang dengan formasi habitat flora dan fauna endemik dipadukan dengan sosial budaya masyarakat lokal turut memperkaya daya tarik ekowisata tersebut. Tumbuhnya kampung-kampung wisata di kepulauan Raja Ampat seperti Arborek (Nuraini et al., 2019) dan Saporkren (Bartholomeus et al., 2013) membuat daerah Raja Ampat menjadi salah satu tujuan ekowisata berbagai wisatawan domestik maupun internasional (Atmodjo et al., 2019).

Ekowisata adalah kegiatan pariwisata yang mengabungkan antara berbagai potensi ekologi, keunikan ekosistem dan budanya masyarakat lokal untuk dijadikan sebagai keunggulan komparatif (Kaharuddin et al., 2020; Yeblo et al., 2015). Masyarakat lokal adalah masyarakat yang berdomisili pada wilayah adat atau masyarakat yang memiliki hak ulayat dan telah diakui secara turun-temurun, baik oleh pemerintah maupun oleh masyarakat lainnya (Lawe Siu et al., 2020; Sinery \& Manusawai, 2017). Keterlibatan masyarakat lokal dalam pengelolaan ekowisata sangat penting karena inisiatif ekowisata berasal dari masyarakat lokal dimana potensi ekowisata itu berada (Oktami et al., 2018)

Beberapa potensi ekowisata yang sudah dikenal wisatawan domestik dan internasional dan ditawarkan dalam paketpaket wisatawan diantaranya adalah Telaga Bintang, Wayag, Teluk Kabui, Pasir Timbul, Pulai Kelelawar, Pianemo,
Kampung Wisata Arborek dan Kampung Saporkren. Disamping itu paket-paket wisata menyelam (diving) dengan menggunakan perahu sewa juga sangat populer. Paket-paket wisata tersebut ditawarkan oleh biro perjalanan, pemandu wisata independen, dan masyarakat lokal.

Kampung Saporkren adalah salah satu kampung di wilayah Distrik Waigeo Selatan, dimana wilayah berbatasan dengan Cagar Alam Waigeo Barat. Kampung ini memiliki bentangan alam yang beragam dari pantai berpasir, terumbu karang, perbukitan dan pegunungan, dimana salah satunya merupakan habitat alami atau area bermain berbagai jenis burung endemik Papua. Diperkirakan di Pulau Waigeo terdapat 171 jenis burung, diantaranya adalah cenderawasih, rangkong, kakak tua hitam, kakak tua jambul kuning, nuri hijau, dan raja udang ((BBKDA Papua Barat, 2018; Putra, 2019). Sepanjang tahun 2017 diperkirakan wisatawan yang mengunjungi kampung Saporkren berjumlah 1000 wisatawan lokal dan mancanegara seperti Inggris, Jerman, Amerika Serikat, Rusia, Perancis dan India, dengan total pendapatan diperkirakan berkisar lebih dari $\mathrm{Rp} 300$ juta, dan oleh karenanya kampung ini mendapat penghargaan sebagai kampung binaan terbaik kedua dari Direktorat Jenderal Konservasi Sumberdaya Alam dan Konservasi, Kementrian Lingkungan dan Kehutanan (Putra, 2019).

Peran serta atau partisipasi masyarakat lokal sebagai masyarakat adat sangat penting dalam pengelolaan sumberdaya alam berkelanjutan dengan kearifan lokalnya dan pemanfaatan ekowisata di daerahnya (Horison et al., 
2020). Kajian tentang tingkat partisipasi masyarakat lokal terhadap ekowisata di Kampung Saporkren belum dilaporkan. Penelitian ini bertujuan untuk mengetahui tingkat, dan bentuk partisipasi masyarakat lokal dalam pengelolaan ekowisata Kampung Saporkren, menganalisis faktor-faktor yang mempengaruhi partisipasi masyarakat lokal, serta mengidentifikasi berbagai manfaat yang diperoleh dari pengelolaan ekowisata di kampung Saporkren.

\section{METODE PENELITIAN}

Penelitian ini dilaksanakan menggunakan metode survey lapangan, pengumpulan data dilakukan dari kelompok responden yang dipilih, dengan mengacu kepada daftar pertanyaan (quisioner) yang telah disiapkan. Sebanyak dua puluh empat responden terlibat dalam pengelolaan dipilih secara sengaja (purposive). Responden tersebut terdiri dari unsur atau kelompok kepala/pimpinan kampung ( 2 responden), kelompok minat (7), kelompok semua anggota rumah tangga (10), wanita (5 responden), dan kelompok remaja (nihil). Pada penelitian ini tidak diperoleh kelompok responden remaja, karena kebanyakan masih usia sekolah.

\section{Alat}

Beberapa peralatan yang dipergunakan dalam penelitian ini diantaranya adalah kamera saku, mini tape recorder, GPS, kalkulator, dan peralatan tulis menulis (stationary) lainnya.

\section{Variabel}

Variabel dalam penelitian ini terdiri dari tingkat partisipasi, bentuk dan intensitas partisipasi, faktor-faktor yang mempengaruhi partisipasi, serta manfaat dari partisipasi dalam pengelolaan ekowisata. Perhitungan tingkat (siapa), bentuk/fungi (dalam apa), dan intensitas (bagaimana) partisipasi mengacu kepada metode yang digunakan oleh Clarence Shubert Pilo (2001) disitasi Sinery dan Manusawai (2017). Tingkat partisipasi masyarakat dihitung dengan metode participation-empowerment index (PEI) (Sinery \& Manusaway, 2017).

Indeks PEI terdiri dari skor pelaku (siapa/who) dengan angka skor dalam hal apa (what) dan skor angka bagaimana (how) masing-masing kelompok responden berpartisipasi dalam kegiatan pengelolaan ekowisata. Indeks tingkat partisipasi lima pelaku (kelompok responden) yaitu kepala/pemimpin (1), kelompok minat (2), seluruh anggota rumah tangga (3), wanita (4) dan anakanak/remaja (5). Lima tingkatan fungsi/bentuk partisipasi, yaitu distribusi atau penggunaan (1), perawatan atau pemeliharaan (2), implementasi (3), perencanaan (4), dan manajemen (5). Sedangkan lima intensitas partisipasi meliputi memberi informasi (1), konsultasi (2), pengambilan keputusan (3), tindakan pra-kegiatan (4), dan jumlah pengendalian (5). Masing-masing indek pelaku tersebut memiliki skor antara 1-5, sehingga apabila dikalikan dengan 5 maka setiap indek (tingkat, fungsi dan intensitas) memiliki skor maksimum 25 dan dikalikan dengan 3 (tiga) menjadi 125. Partisipasi masyarakat di nilai sangat aktif bila memiliki total skor antara 101125 , aktif dengan nilai 76-100, cukup aktif nilai 51-75, tidak aktif nilai 26-50, dan sangat tidak aktif jika nilai skor totalnya antara 1-25.

\section{HASIL DAN PEMBAHASAN}

\section{Potensi ekowisata}

Masyarakat lokal kampung Saporkren terdiri dari tiga marga besar yaitu Mambrasar, Dimara, dan Sauyai dan telah berdomisili sejak akhir perang dunia ke I tahun 1942. Kampung Saporkren dapat dijangkau dengan menggunakan transportasi darat dan laut, dengan rata-rata waktu tempuh selama 30 menit dengan kendaraan roda dua dan empat dari ibukota kabupaten Raja Ampat Waisai. Sedangkan dengan kendaraan laut, memerlukan waktu sekitar 20 menit. Berdasarkan data Badan Statistik Kabupaten Raja Ampat tahun 2020 penduduk Kampung Saporkren berjumlah 664 jiwa yang terbagi dalam 
150 kepala keluarga $(\mathrm{KK})$ dengan jumlah penduduk per KK adalah 4.4 jiwa (Badan Pusat Statistik kabupaten Raja Ampat, 2020), dengan topograpi yang berbukit, dengan ketinggian bukit antara 20-30 m diatas permukaan laut. Bentang alam Kampung Saporkren juga terdiri dari perairan, pebukitan, dan pantai berpasir putih ((BBKDA Papua Barat, 2018).

Hasil penelitian menunjukkan bahwa potensi ekowisata di Kampung Saporkren diantaranya adalah pemanggilan burung cenderawasih (bird watching) dengan jenis Cenderawasih botak (Cicinnurus republica) dan Cenderawasih merah (Paradisaea rubra). Wisata pemangilan burung tersebut oleh masyarakat lokal dinamakan dengan sebutan atraksi cenderawasih berdansa. Wisatawan yang akan menyaksikan atraksi tersebut harus rela bangun pada pukul lima pagi dan bejalan mendaki bukit sekitar 30-60 menit, dan atraksi tersebut berlangsung selama kurang lebih 30 menit. Wisatawan yang datang ke kampung Saporkren biasanya menginap di penginapan milik masyarakat (homestay) dan menikmati lebih dari satu potensi ekowisata yang ada, seperti menyelam, mendaki bukit (hiking), dan menjelajahi goa-goa tempat bersejarah.

\section{Tingkat partisipasi}

Hasil analisis perhitungan skor dari fungsi/bentuk dan intensitas partisipasi dari masing-masing kelompok responden untuk menentukan tingkat partisipasi, yang dinyatakan dalam PEI, dapat diringkas pada Tabel 1 .

Tabel 1. Rata-rata skoring fungsi dan intensitas partisipasi dari masing-masing responden untuk menentukan tingkat partisipasi masyarakat lokal dalam pengelolaan ekowisata di Kampung Saporkren

\begin{tabular}{|c|c|c|c|c|c|c|c|}
\hline \multirow{2}{*}{$\begin{array}{l}\text { Variabel } \\
\text { Partisipasi }\end{array}$} & \multicolumn{6}{|c|}{ Respondent (siapa) } & \multirow[b]{2}{*}{ Jumlah } \\
\hline & & $\begin{array}{l}\text { Kepala/ } \\
\text { Pemimpin }\end{array}$ & $\begin{array}{l}\text { Kelompok } \\
\text { minat }\end{array}$ & $\begin{array}{l}\text { Seluruh } \\
\text { rumah } \\
\text { tangga }\end{array}$ & Wanita & $\begin{array}{l}\text { Anak- } \\
\text { anak/ } \\
\text { remaja }\end{array}$ & \\
\hline Fungsi/ & 5. Managemen & - & - & & - & - & - \\
\hline bentuk & 4. Perencanaan & 2 & - & - & - & - & 2 \\
\hline (dalam & 3. Implementasi & - & 7 & - & - & - & 7 \\
\hline \multirow[t]{2}{*}{ apa) } & $\begin{array}{l}\text { 2. Perawatan/ } \\
\text { Pemeliharaan }\end{array}$ & - & - & 6 & - & - & 6 \\
\hline & 1. Distribusi & - & - & 4 & 5 & - & 9 \\
\hline \multicolumn{2}{|c|}{ Jumlah (responden) } & 2 & 7 & 10 & 5 & 0 & 24 \\
\hline \multicolumn{2}{|l|}{ Persen $(\%)$} & 8.33 & 29.17 & 41.67 & 20.83 & 0.00 & 100 \\
\hline \multirow[t]{5}{*}{$\begin{array}{l}\text { Intensitas } \\
\text { (bagaimana) }\end{array}$} & $\begin{array}{l}\text { 5. Jumlah } \\
\text { pengendalian }\end{array}$ & 1 & - & - & - & - & \\
\hline & $\begin{array}{l}\text { 4. Tindakan pra } \\
\text { kegaitan }\end{array}$ & - & - & - & - & - & \\
\hline & $\begin{array}{l}\text { 3. Pengambilan } \\
\text { keputusan }\end{array}$ & 1 & - & 2 & 1 & - & \\
\hline & 2. Konsultasi & - & 2 & 3 & 1 & - & \\
\hline & $\begin{array}{l}\text { 1. Memberi } \\
\text { informasi }\end{array}$ & - & 5 & 5 & 3 & - & \\
\hline \multicolumn{2}{|c|}{ Jumlah (responden) } & 2 & 7 & 10 & 5 & 0 & 24 \\
\hline \multicolumn{2}{|l|}{ Persen $(\%)$} & 8.33 & 29.17 & 41.67 & 20.83 & 0.00 & 100 \\
\hline \multicolumn{2}{|l|}{ Nilai indeks } & $12(1)$ & $12(2)$ & $18(2)$ & $12(1)$ & - & \\
\hline \multirow[t]{2}{*}{ PEI } & & $20(1)$ & $06(5)$ & $12(3)$ & $8(1)$ & & \\
\hline & & & & $06(5)$ & $4(3)$ & & \\
\hline \multicolumn{2}{|c|}{ Tingkat partisipasi } & \multicolumn{5}{|c|}{ sangat tidak aktif (1-25) } & \\
\hline \multicolumn{8}{|c|}{$\begin{array}{l}\text { PEI } \quad \text { sangat aktif(101-125);aktif(76-100);cukup aktif(51-75);tidak aktif(26-50);sangat tidak aktif(1-25) } \\
\text { standar }\end{array}$} \\
\hline
\end{tabular}


Berdasarkan Tabel 1, dapat disimpulkan bahwa tingkat partisipasi masyarakat lokal di Kampung Saporkren, dari lima unsur pelaku (who) yaitu unsur pemimpin, kelompok minat, anggota rumah tangga, wanita dan remaja digolongkan sangat tidak aktif dengan nilai indek PEI antara 1-15.

Tingkat partisipasi masyarakat lokal ini lebih rendah dari pada kegiatan ekoturisme dalam pengelolaan ekowisata mangrove di kelurahan Oesapa Barat kota Kupang (Lawe Siu et al., 2020), dan pengembangan ekowisata pada kawasan taman wisata alam Tanjung Belimbing kecamatan Paloh Kabupaten Sambas (Elisca et al., 2020). Akan tetapi partispasi atau keterlibatan masyarakat terhadap pelestarian hutan Cagar Alam di kampung Saporkren distrik Waigeo Selatan mencapai angka 55\%, dari total 20 kepala keluarga (KK) responden (Irnawati, 2019). Hal tersebut diduga karena kegiatan menjaga atau melestarikan hutan tidak memerlukan keahlian khusus, seperti halnya pengelolaan ekowisata, yang diawali dari pemahaman ekowisata, persepsi ekowisata, dan berbagai pengetahuan lainnya (Rohman et al., 2016).

Tingkat partisipasi kelompok kepala/pimpinan sangat tidak aktif (1-25) dengan nilai indek PEI $(12,20)$ dengan bentuk partisipasi pengelolaan ekowisata adalah perencanaan $(8.3 \%)$ dan intensitas partisipasi dalam pengendalian $(4.1 \%)$ dan pengambilan keputusan $(4.1 \%)$. Hal ini diduga bahwa kepala/pemimpin lebih berperan dalam perencanaan, pengambilan keputusan, dan pengendalian pengelolan ekowisata di Kampung Saporkren bersifat top down atau pendekatan dari dari atas ke bawah. Dalam kelembagaan masyarakat lokal, kepala/pimpinan lebih bersifat sentralistik, atau bersifat ketokohan, baik tokok masyarakat, agama maupun tokoh pemerintahan, dibandingkan dengan kemampuan managerial berdasarkan kompetensi (Elisca et al., 2020).

Tingkat partisipasi kelompok minat pada pengelolaan ekowisata di Kampung Saporkren termasuk dalam kategori sangat tidak aktif, dengan indek PEI adalah 12 dan 06. Fungsi partisipasi kelompok ini dalam hal implementasi (19.2\%) dengan intensitas partisipasi dalam bentuk konsultasi (8.3\%) dan memberi informasi (20.8\%). Meskipun tingkat partisipasi dari unsur seluruh anggota rumah tangga adalah sangat tidak aktif, dengan index PEI adalah 18,12 dan 06, tetapi kelompok ini memiliki fungsi partisipasi yang sangat dominan $(41.7 \%)$ dalam perawatan dan distribusi, sedangkan pada intensitas partisipasi meliputi pengambilan keputusan $(8.3 \%)$, konsultasi $(12.5 \%)$, dan memberi informasi (20.8\%).

Seluruh anggota keluarga diduga terlibat aktif dalam kegiatan homestay, seperti pengelolaan homestay, speedboat motorist, tour guide and beberapa kegiatan terkait lainnya. Tingkat partisipasi kelompok wanita dalam pengelolaan ekowisata juga dikategorikan sangat tidak aktif, dengan nilai indeks PEI adalah 12, 8, dan 4. Bentuk partisipasi kelompok ini hanya pada distribusi (20.8\%) dengan intensitas partisipasi dalam hal pengambilan keputusan (4.1\%), konsultasi (4.1\%) dan memberi informasi (12.5\%). Tingkat partisipasi kelompok remaja pada pengelolaan ekowisata adalah nihil. Kelompok ini diharapkan menjadi motor pengerak dalam pengelolaan, karena merupakan generasi penerus untuk melanjutkan pengelolaan di masa mendatang. Rendahnya tingkat partisipasi kelompok reseponden tersebut diduga karena kurangnya pemahaman terhadap konsep ekowisata dan minimnya pengetahuan tentang ekowisata, dan yang mana peran serta aktif masyarakat dari perencanaan sampai dengan pengambilan keputusan dan evaluasi kegiatan (Marysya \& Amanah, 2018; Triyanti et al., 2020).

\section{Fungi atau bentuk partisipasi}

Dari tabel 1 dapat dijelaskan bahwa berdasarkan fungsi partisipasinya kelima kelompok responden tidak berpartisipasi dalam manajemen. Dalam pembinaan pengelolaan ekowisata di Kampung Saporkren, fungsi partisipasi dalam manajemen perlu ditingkatkan dan 
hal tersebut perlu mendapat perhatian dari instansi teknis pemerintah daerah dan pusat, organisasi pendamping masyarakat dan motivator. Bentuk partisipasi masyarakat lokal dalam pengelolaan ekowisata di kampung Saporkren yaitu perencanaan didominasi oleh kepala/pemimpin (8.3\%), sedangkan kelompok minat dominan dalam bentuk implementasi kegiatan (29.2\%) serta semua anggota rumah tangga sangat

\section{Intensitas partisipasi}

Intensitas partisipasi dari lima kelompok responden dari masyarakat lokal di Kampung Saporkren beragam (Tabel 1), dimana intensitas partisipasi pemimpin lebih dominan pada jumlah pengendalian dan pengambilan keputusan, kelompok minat pada konsultasi dan memberi informasi. Sebaliknya intensitas partisipasi anggota rumah tangga dan wanita dalam pengambilan keputusan, konsultasi dan memberikan informasi. Sehingga kelompok anggota rumah tangga dan wanita merupakan dua kelompok yang sangat dominan, memiliki intensitas partisipasi tertinggi, dalam pengelolaan ekowisata di Kampung Saporkren. Akan tetapi intensitas partisipasi dalam inisiasi kegiatan adalah nihil atau belum dapat dilakukan oleh kelima unsur kelompok responden masyarakat lokal di Kampung Saporkren, khususnya dalam pengelolaan ekowisata. Hal ini kemungkinan dominan $41.7 \%$ terdiri dari perawatan (25\%) dan distribusi (16.7\%). Bentuk partisipasi dari kelompok wanita atau ibu rumah tangga sebesar $20.8 \%$ pada kelompok distribusi. Bentuk partisipasi dari responden tidak menunjukkan kelompok yang berperan dalam fungsi manajemen, hal ini sangat disayangkan, dan menjadi catatan penting untuk dipertimbangkan di masa mendatang (Sutrisno, 2015).

disebabkan proses inisiasi kegiatan awalnya dilakukan oleh pihak luar, yaitu Balai Besar Konservasi Sumber Daya Alam (BBKSDA) Provinsi Papua Barat, yang berdomisili di Kota Sorong.

\section{Faktor-faktor yang mempengaruhi partisipasi}

Hasil penelitian tentang persepsi yaitu faktor-faktor yang mempengaruhi kemauan dan alasan masyarakat lokal berpartisipasi dalam pengelolaan ekowisata di Kampung Saporkren dapat diringkas pada Tabel 2 .

Tabel 2 menjelaskan bahwa persepsi masyarakat tentang partisipasi dalam ekowisata bahwa ini adalah proram pemerintah yang disosialisasikan oleh instansi terkait $(70.8 \%)$ yang harus didukung dan disukseskan. Disamping itu masyarakat berpendapat bahwa sosialisasi program ekowisata dan pengelolaannya dilakukan secara sederhana, hanya sosialisasi $(20.8 \%)$ dan penuh dengan keterbukaan $(8.3 \%)$.

Tabel 2. Faktor-faktor yang mempengaruhi kemauan dan alasan masyarakat lokal berpartisipasi dalam pengelolaan ekowisata di Kampung Saporkren

\begin{tabular}{lrlcc}
\hline \multicolumn{1}{c}{ Persepsi } & & \multicolumn{1}{c}{ Faktor } & $\begin{array}{c}\text { Jumlah } \\
\text { responden }\end{array}$ & $\begin{array}{c}\text { Persen } \\
(\%)\end{array}$ \\
\hline $\begin{array}{l}\text { Kemauan } \\
\text { berpartisipasi }\end{array}$ & 1. & $\begin{array}{l}\text { Keterbukaan BBKSDA Papua Barat untuk } \\
\text { melibatkan masyarakat lokal }\end{array}$ & 2 & 8.33 \\
& 1. & Sosialisasi & 5 & 20.83 \\
& 2. & Penyuluhan dari instansi terkait & 17 & 70.83 \\
\hline & $\quad$ Jumlah & 24 & 100 \\
\hline Alasan & 1. & Kewajiban. Tanggung jawab dan rasa memiliki & 5 & 20.83 \\
berpartisipasi & 2. & Diajak oleh petugas BBKSDA Papua Barat & 10 & 41.67 \\
& 3. & Dapat memperoleh pendapatan & 9 & 37.50 \\
\hline & $\quad$ Jumlah & 24 & 100 \\
\hline
\end{tabular}


Persepsi masyarakat lokal kenapa terlibat atau berpartispasi dalam pengelolaan ekowisata dikarenakan diajak oleh petugas BBKSDA (41.7\%), mendapat upah atau pendapatan $(37.5 \% 0$, dan merupakan kewajiban, tanggung jawab dan rasa memiliki terhadap sumber daya alam di wilayahnya (20.83\%).

Faktor faktor dominan yang berkontribusi terhadap partisipasi masyarakat lokal dalam pengelolaan ekowisata di wilayahnya adalah bentuk transparansi pemerintah (daerah dan pusat) dalam melibatkan langsung masyarakat lokal dalam pengembangan potensi ekowisata di daerahnya. Kewajiban, tanggung jawab dan rasa memiliki akan potensi sumberdaya alam di wilayah adatnya juga merupakan faktor yang mendorong masyarakat ikut berpartisipasi dalam pengelolaan kawasan ekowisata (Kaharuddin et al., 2020; Tuasikal, 2020) . Faktor terakhir yang berkontribusi langsung kepada masyarakat lokal, seperti imbalan dari keikutsertaan dalam partisipasi, peluang pekerjaan dan usaha serta memperkenalkan budaya lokal.

\section{Manfaat partisipasi}

Masyarakat lokal memperoleh berbagai manfaat baik langsung maupun tidak langsung dari partisipasi dalam pengelolaan ekowisata di Kampung Saporkren. Manfaat langsung dalam pengelolaan ekowisata di Kampung Saporkren oleh masyarakat diantaranya adalah menyediakan rumah sewa (homestay) kepada tamu, menyediakan cenderamata lokal, transportasi laut (speed boat), perahu dayung (boat), kayak (cano), dan menjadi pemandu wisata, dan kader konservasi. Fasilitas rumah sewa dan sarana transportasi laut milik masyarakat lokal dapat dilihat pada Gambar 1. Disamping itu, kampung Saprokren juga memungut retribusi kampung untuk pemeliharaan dan konservasi sumberdaya alam, dalam bentuk karcis masuk di pintu gerbang memasuki kampung ekowisata Saporkren (Gambar 2).
Disamping manfaat langsung, masyarakat lokal juga merasakan manfaat tidak langsung dari pengelolaan ekowisata. Program-program ekowisata dari berbagai lembaga pemerintah, baik pemerintah pusat melalui Kementrian Kehutanan, saat ini Kementrian Lingkungan Hidup dan Kehutanan, dan Dinas Pariwisata Kabupaten Raja Ampat, telah membuat Kampung Saporkren menjadi tujuan ekowisata di Raja Ampat (Bartholomeus et al., 2013; Putra, 2018; Sutrisno, 2015).

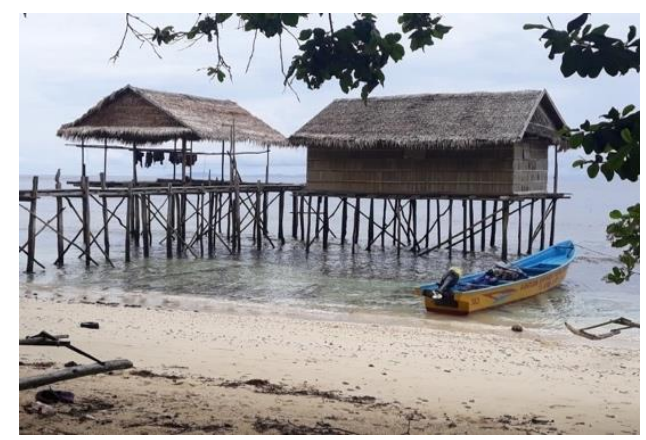

Gambar 1. Rumah sewa (homestay) dan alat transportasi laut milik masyarakat lokal di kampung Saporkren

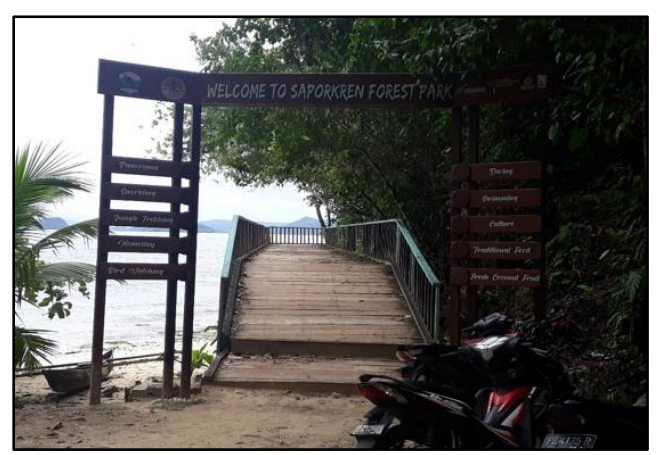

Gambar 2. Pintu gerbang ekowisata Kampung Saporkren

Manfaat dari program yang telah dilakukan adalah bertambahnya pengetahuan dan wawasan masyarakat lokal tetang ekowisata, kapasitas masyarakat lokal meningkat, dan terbentuknya beberapa kelembagaan masyarakat lokal di Kampung Saporkren. Beberapa manfaat tidak langsung dari 
program ekowisata pemerintah di kampung Saporkren diantaranya adalah:

a. Pengembangan pemandu wisata (tour guide). Program ini dilakukan dengan mendidik masyarakat lokal untuk menjadi pemandu ekowisata di kampung Saporkren, baik wisata bahari maupun pemanggilan burung (bird watching).

b). Smart patrol. Program bersama antara lembaga konservasi dengan masyarakat lokal dalam mengawasi dan melindungi kawasan Cagar Alam Waigeo Barat.

c). Kelompok Tani Hutan (KTH). Partisipasi masyarakat lokal dalam program ini adalah dengan menjaga kawasan hutan di sekitar kampung dengan kegiatan bercocok tanam atau berkebun untuk kebutuhan sehari-hari atau untuk dijual dalam skala terbatas.

d). Kader konservasi Alam (KKA). Anggota masyarakat lokal yang telah diberi pelatihan dan bekal pengetahuan tentang konservasi sumberdaya alam dan bertugas melakukan edukasi kepada anggota kelompok masyarakat baik secara formal maupun informal.

e. Marine Protected Area (MPA). Bersama masyarakat lokal menetapkan kawasan pasang-surut pantai dan daerah luarnya untuk tetap dijadikan kawasan perlindungan flora, fauna dan budaya mayarakat setempat.

\section{KESIMPULAN}

Kesimpulan yang dapat dirumuskan diantaranya adalah bahwa tingkat partisipasi kelima kelompok respondent masyarkat lokal, yaitu kepala/pemimpin, kelompok minat, semua anggota rumah tangga, wanita dan anak-anak/remaja disimpulkan sangat tidak aktif (1-25), dengan rata-rata indek PEI dibawah 15, bahkan tingkat partispasi unsur anak-anak/remaja adalah nihil. Bentuk partisipasi kelompok kepala/pemimpin lebih dominan pada pengambilan keputusan dan kontrol keadaan, sedangkan kelompok lainnya pada implentasi, perawatan dan distribusi. Intensitas partisipasi dalam pengambilan keputusan, konsultasi dan pemberi informasi lebih banyak dilakukan oleh kelompok anggota rumah tangga, kelompok minat dan wanita. Manajemen dan inisiasi kegiatan adalah fungsi dan intensitas partispasi yang belum dilakukan oleh lima kelompok responden dalam pengelolaan ekowisata di Kampung Saporkren.

\section{UCAPAN TERIMA KASIH}

Penulis mengucapkan banyak terima kasih kepada masyarakat adat di Kampung Saporkren yang telah menerima dan menemani penulis selama melaksanakan penelitian pada saat pandemi Covid 19 ini, dengan tetap menggunakan protokol kesehatan.

\section{DAFTAR PUSTAKA}

Atmodjo, E., Lamers, M., \& Mol, A. P. J. 2019. Governing Dynamics in Marine Conservation Tourism in Raja Ampat, Indonesia. Tourism Planning \& Development, 1-19. https://doi.org/10.1080/21568316. 2019.1686652

BPS.,kabupaten Raja Ampat. 2020. Distrik Wigeo Selatan Dalam Angka 2020.

Bartholomeus, M.L.R., Runtuboi, D.Y.P \& Tanjung, R.H. 2013. Konservasi dan Kondisi Terumbu Karang di Kampung Saporkren Distrik Waigeo Selatan, Kabupaten Raja Ampat, Papua Barat. Journal Biologi Papua 5(2), 68-76.

BBKDA Papua Barat. (2018). Awesome West Papua. Let,s Visit and Explore our Ecotourism Site. BBKSDA Papua Barat.

Elisca, Idham, M., \& Iskandar. 2020. Partisipasi masyarakat dalam pengembangan ekowisata pada kawasan taman wisata alam tanjung 
belimbing kecamatan Paloh kabupaten Sambas. Hutan Lestari Jurnal as. 8(13), 478-490.

Horison, Hertati, R., \& Kholis, M. N. 2020. Tingkat partisipasi masyarakat terhadap suaka perikanan (reservat) lubuk kasai perairan Batang Pelepat kabupaten Bungo Provinsi Jambi. SEMAH: Jurnal Pengelolaan SUmberdaya Perairan, 4(1), 1-16.

Irnawati, I. 2019. Partisipasi Masyarakat Terhadap Pelestarian Hutan Cagar Alam Di Kampung Saporkren Distrik Waigeo Selatan Kabupaten Raja Ampat. Median : Jurnal Ilmu Ilmu Eksakta, 10(1), 28. https://doi.org/10.33506/md.v10i1. 153

Kaharuddin, K., Pudyatmoko, S., Fandeli, C., \& Martani, W. 2020. Partisipasi Masyarakat Lokal dalam Pengembangan Ekowisata. Jurnal Ilmu Kehutanan, 14(1), 42.https://doi.org/10.22146/jik.574 62

Lawe Siu, M. G., Amanah, S., \& Santoso, N. 2020. Partisipasi masyarakat lokal dalam pengelolaan ekowisata mangrove di kelurahan oesapa barat kota kupang. Jurnal TENGKAWANG, 10(1). https://doi.org/10.26418/jt.v10i1.4 0663

Marysya, P., \& Amanah, S. 2018. Community Participation inTourism Management based on Village Tourism Potential in Situ Gede, Bogor. Jurnal Sains Komunikasi dan Pengembangan Masyarakat [JSKPM], 2(1), 59. https://doi.org/10.29244/jskpm.2.1. $59-70$

Nuraini, Arif Satria, \& Ekawati Sri Wahyuni. 2019. Mekanisme Akses dan Kekuasaan dalam Memperkuat Kinerja Institusi Pengelolaan Ekowisata Bahari (Studi Kasus: Kampung Wisata Arborek, Distrik Meos Mansar, Kabupaten Raja Ampat, Provinsi Papua Barat). Solidity: Jurnal Sosiologi Pedesaan, April, 65-77.
Oktami, E. A., Sunarminto, T., \& Arief, D. H. 2018. Partisipasi masyarakat dalam pengembangan ekowisata taman hutan raya Ir $\mathrm{H}$ Djuanda. Media Konservasi, 23(3), 236-243.

Putra, L. M. 2018. Kader Konservasi Tanah Saporkren. www.econusa.id (diakses, 17 Nov. 2020)

Rohman, F., Ghofar, A., \& Saputra, S. W. 2016. Partisipasi masyarakat dalam pengembangan kawasan ekowisata di desa Bedono kecamatan Sayung kabupaten Demak. Diponegoro Journal of Marquares, 5(2),61-69.

Sinery, A. S., \& Manusawai, J. (2017). Partisipasi masyarakat dalam program pengelolaan hutan lindung wosi rendani (Participation of Communities in the Wosi Rendani Protected Forest Management). Jurnal Manusia dan Lingkungan, 23(3), 394-401. https://doi.org/10.22146/jml.18811

Sutrisno, W. 2015. Analisis supply bagi standar manajemen pengembangan di kawasan ekowisata Raja Ampat. Journal of Applied Buisiness and Economics, 1(4), 241-255.

Triyanti, R., Muawanah, U., Kurniasari, N., Soejarwo, P. A., \& Febrian, T. 2020. Potensi pengembangan ekowisata bahari berbasis masyarakat adat sebagai kegiatan ekonomi kreatif di kampung Malaumkarta, Papua Barat. Jurnal Sosial Ekonomi Kelautan dan Perikanan, 15(1), 93-105. https://doi.org/10.15578/jsekp.v15i 1.8239

Tuasikal, T. 2020. Strategi pengembangan ekowisata pantai Nitanghahai di desa Morela, kabupaten Maluku Tengah. Jurnal Agrohut, 10(1), 3244.

Yeblo, M., Kiroh, H. J., Nangoy, M. J., \& Rawung, V. R. W. 2015. Studi beberapa faktor pendukung pengembangan ekowisata berbasis fauna endemik di hutan Sawinggrai kecamatan Miosmansar kabupaten kepulauan Raja Ampat propinsi Papau Barat. ZOOTEC, 35(2), 210. 
https://doi.org/10.35792/zot.35.2.2

015.7843 